\title{
Contribution to the knowledge of the terrestrial isopod fauna of Lithuania
}

\author{
Ingrida Šatkauskienė \\ Vytautas Magnus University, \\ K. Donelaičio g. 58, \\ Kaunas 44248, Lithuania
}

\begin{abstract}
The present survey provides records on terrestrial isopods from southern and north-western parts of Lithuania. Isopods were sampled manually by checking substrates in eight habitats (several types of forest and anthropogenic environment) between 2014 and 2016. In total, seven species were recorded. The common European species Trachelipus rathkii was noted as the most frequent isopod in all studied habitats from southern Lithuania. Porcellionides pruinosus, found in the habitat of anthropogenic activity, was recorded for the first time from Lithuania. Based on the data of the present study and previous surveys, the 14 species of terrestrial isopods are recorded in Lithuania and the current state of knowledge about Lithuanian isopod is summarised.
\end{abstract}

Keywords: woodlice, isopoda, Oniscidae, Lithuania

\section{INTRODUCTION}

Isopods (Broly et al., 2013), the tiny creatures that live in old forests or other terrestrial habitats with numerous shelters and feed on plant litter, play an important role in decomposition processes (Zimmer, 2002). Forests cover approximately 33\% of the territory of Lithuania, but some of its areas are changed growing numbers of residential houses with adjoining mown lawns that do not provide shelter for the invertebrates discussed. Fortunately, such ecosystems as old woodlands and wetlands are protected and remain inviolable, hence guarantee a living environment for invertebrates. Despite the wide distribution of terrestrial isopods (Schmalfuss 2003; Sfenthourakis, Taiti, 2015), so far the current knowledge on Lithuanian isopod fauna is incomplete. Not only we do not

\footnotetext{
* Corresponding author. Email: ingrida.satkauskiene@vdu.lt
}

know the exact list of isopod species, but also how the species are distributed across the regions of Lithuania; we do not know which species can be considered rare or invasive in our country.

In addition, we cannot compare the changes in the communities of isopods during time, because studies in Lithuania, studies into terrestrial isopods started only in 2012. To date, 13 species of terrestrial isopods are known from Lithuania: Ligidium hypnorum (Cuvier, 1792) Ligiidae Brandt \& Ratzeburg, 1831: Ligia Fabricius, 1798, Trichoniscidae Sars, 1899: Haplophthalmus danicus Budde Lund 1880; Hyloniscus riparius (C. Koch, 1838), Trichoniscus pusillus Brandt, 1833. Philosciidae Vandel, 1962: Oniscidae Latreille, 1806: Oniscus asellus Linnaeus, 1758; Platyarthridae Verhoeff, 1949: Platyarthrus hoffmannseggii Brandt, 1833 Porcellionidae Brandt \& Ratzeburg, 1831: Porcellio scaber Latreille, 1804, Porcellio spinicornis Say, 1818, Cylisticidae Vandel, 1963: Cylitiscus convexus (De Geer, 1778); Trachelipodidae Strouhal, 1953: Trachelipus 
rathkii (Brandt, 1833), Porcellium conspersum (Koch, 1841). Armadillidiidae Brandt, 1833: Armadillidium vulgare (Latreille, 1804), Armadillidium pulchellum (Zenker, 1799) (Kuznetsova, Gongalsky 2012, Vilisics et al., 2012; Tuf et al., 2014, Šatkauskiene, 2017).

The aim of this paper is to summarise the current state of knowledge on Lithuanian isopods based on the data of previous surveys and adding data on the isopods found in southern and north-western parts of Lithuania between 2014 and 2016.

\section{METHODS}

\section{Study area and the climate data}

Lithuania, the largest of the three Baltic countries, is located at the edge of the East European plain with coordinates of $55^{\circ} 10^{\prime} 10^{\prime \prime} \mathrm{N}$ latitude and $23^{\circ} 52^{\prime} 52.6^{\prime \prime} \mathrm{E}$ longitude. Lithuania is glacially flat, except for morainic hills in western uplands and eastern highlands no higher than 300 metres. The terrain is marked by numerous small lakes and swamps, and a mixed-forest zone covers over $33 \%$ of the country (Bukantis et al., 2013).

Lithuania's climate is humid, with moderating effects from the Baltic Sea. January is the coldest month with daytime temperatures usually around $-5^{\circ} \mathrm{C}$ and July is the warmest month with an average temperature of $18^{\circ} \mathrm{C}$. The average annual precipitation is $661 \mathrm{~mm}$ (Lithuanian Hydrometeorological Service under the Ministry of Environment). Compared to the other localities of Lithuania, more pronounced contrasts of seasonal temperature are characteristic of the southern region. In spring and summer, the average monthly air temperature here is $1.0^{\circ} \mathrm{C}$ higher than in the western or northern regions of the country. Higher fluctuations of daily temperatures typical in the southern part of the country. These variations are affected by sandy areas, which are warm easily (in summer, sand surfaces can heat up to $50^{\circ} \mathrm{C}$ ) and quickly deliver the accumulated heat (Natural Heritage Foundation 2014). A survey of isopods was con-

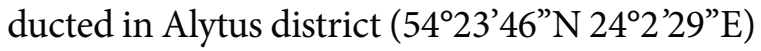
in the southern part of Lithuania (Fig. 1).

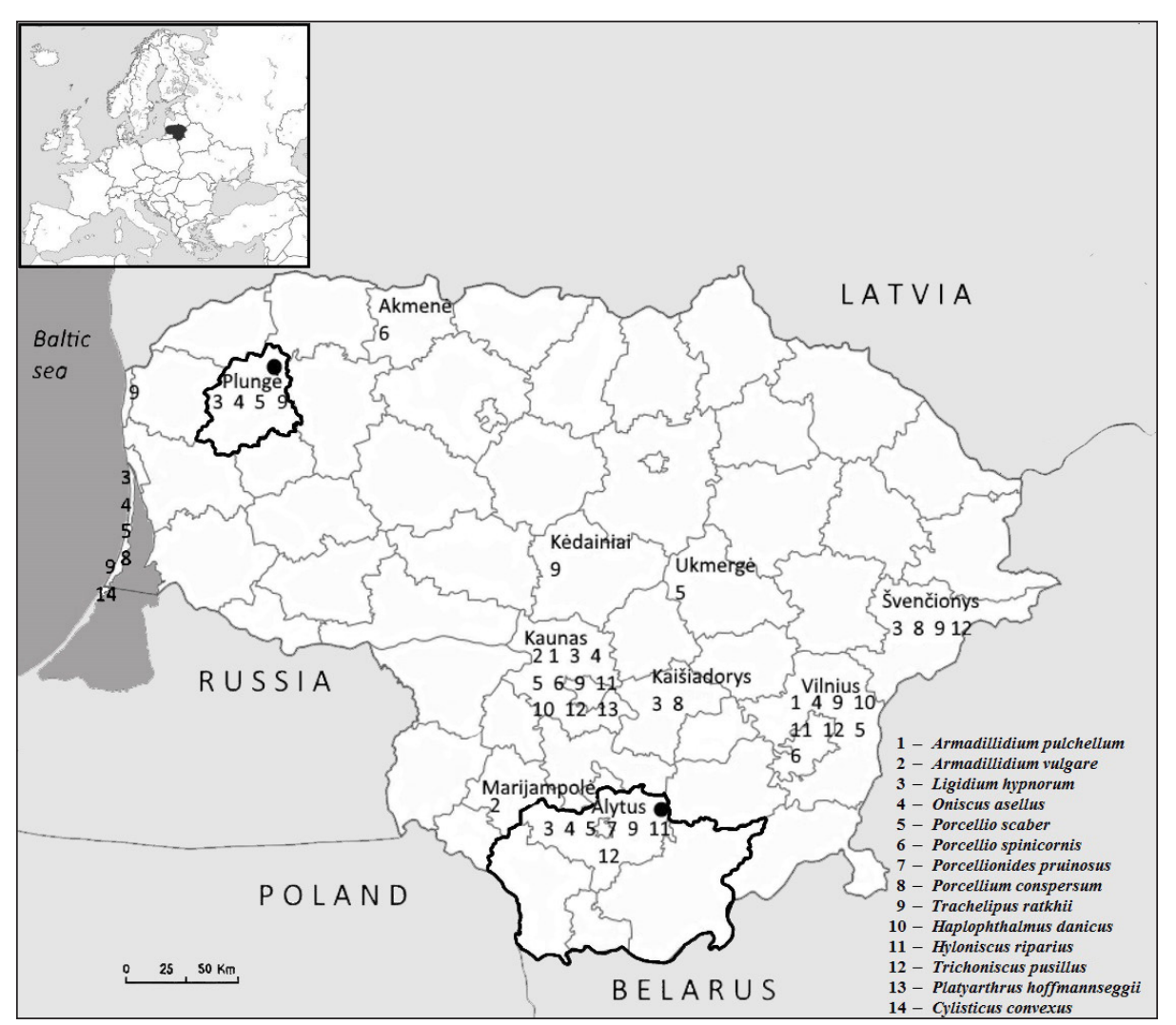

Fig. 1. Map of the sampling and distribution of terrestrial isopods in Lithuania. Data are based on the records in the literature from 2012 to 2017 and the present study (districts in the southern and north-western regions Lithuania are marked by bold line) 
Pine forests and woodlands cover almost half (44\%) of Alytus district. Sandy soil and gravel constitute $93.7 \%$ of the region soil and are acidic due to intense leaching processes of $\mathrm{Ca}^{2+}, \mathrm{Mg}^{2+}$, clay particles, and iron oxides from the deep layer of soils (Mažvila et al., 2004). The north-western part of Lithuania is hilly and the terrain causes high precipitation $(700 \mathrm{~mm})$, more pronounced micro-climatic differences, and the formation of small wetlands. In this part of the country, isopods were surveyed in Plokštinè Reserve (PR) (56 $\left.1^{\circ} 39^{\prime \prime} \mathrm{N} 21^{\circ} 54^{\prime} 33^{\prime \prime} \mathrm{E}\right)$ (Fig. 1) that aims to preserve woods and marsh with ecosystems typical of this region. No forestry, agriculture, or any other type of economic activity is permitted here.

\section{Assessment of habitat features}

Six habitats were selected to represent isopod diversity in southern part of Lithuania (Alytus district) and two in north-western Lithuania (Plokštinè Reserve, Plunge district).

The characteristics of the habitats (names of dominant or characteristic plants; exposure; soil characteristics: type of soil and $\mathrm{pH}$; litter properties: thickness, composition, and $\mathrm{pH}$ ) and their abbreviations are listed below:

Deciduous forest (DDF) $\left(54^{\circ} 23^{\prime} 44.4^{\prime \prime} \mathrm{N}\right.$ $24^{\circ} 05^{\prime} 11.1$ 'E) - dominated by Alnus glutinosa and Corylus avellane. The dense canopy layer of growing trees partly keeps the sun from penetrating to the lower layers of the forest. The soil was sandy loam with $\mathrm{pH} 7.38 \pm 0.1$. Litter, formed by leaves of A. glutinosa and C. avellane, was about $4 \mathrm{~cm}$. Litter pH $6.69 \pm 0.2$.

Small deciduous forest (DF) (0.48 he) ( $\left.54^{\circ} 23^{\prime} 38^{\prime \prime} \mathrm{N} 24^{\circ} 06^{\prime} 28^{\prime \prime} \mathrm{E}\right)$ - light and dry, located beside the road and formed by Populus tremula, Betula pendula, and scarce Quercus robur. The soil was cohesive sand, with pH $6.1 \pm 0.5$. Litter, consisting of leaves and fallen bark of P. tremula, Q. robur was $\approx 2-2.5 \mathrm{~cm}$ and $\mathrm{pH}$ $6.7 \pm 0.1$.

Broadleaf forest (BLF) $\left(54^{\circ} 23^{\prime} 17^{\prime \prime} \mathrm{N} 24^{\circ} 06^{\prime}\right.$ 17"E) - Q. robur, Tilia cordata, Acer platanoides, Ulmus sp. dominated here. Sandy loam soil dominated here, $\mathrm{pH} 4.7 \pm 0.2$. Litter was formed of the leaves and fallen bark of the mentioned tree. The thickness of litter was $\approx 2.5-3 \mathrm{~cm}$ and pH $6.45 \pm 0.1$.

Anthropogenic habitat (AH) $\left(54^{\circ} 23^{\prime} 38^{\prime \prime} \mathrm{N}\right.$ $\left.24^{\circ} 06^{\prime} 57^{\prime \prime} \mathrm{E}\right)$ - selected around houses: compost, agricultural residues, cellars, and plots of soil with vegetation: Poa annua, Potentilla anserina, Chamomilla suaveolens, Taraxacum officinale, Polygonum aviculare. The soil was sandy loam with pH $7.05 \pm 0.2$. Litter was absent.

Mixed forest with dominating Pinus silvestris (MFP) $\left(54^{\circ} 25^{\prime} 22^{\prime \prime} \mathrm{N} 24^{\circ} 03^{\prime} 12^{\prime \prime} \mathrm{E}\right)$ - addition to P. silvestris, Quercus robur, Betula pendula, and C. avellana grow here. Sandy soil, $\mathrm{pH} 4.57 \pm 0.1$. Litter was formed of pine tree needles, moss (Bryophyta), and leaves of deciduous trees. The thickness of litter was about $2.5-3 \mathrm{~cm}$ and $\mathrm{pH} 6.6 \pm 0.16$.

Recovering young mixed forest (RMF) $\left(54^{\circ} 24^{\prime} 43^{\prime \prime} \mathrm{N} 24^{\circ} 04^{\prime} 43^{\prime \prime} \mathrm{E}\right)$ - a former clear-cutting forest, now recovered by young $P$. silvestris, in addition to Picea abies, and sporadic B. pendula. Soil was cohesive sand with pH $6.41 \pm 0.1$. Litter was poor (thickness $\approx 1 \mathrm{~cm}$ ) formed of pine tree needles and coarse birch leaves. Litter pH $5.6 \pm 0.2$.

Mixed coniferous forest (MCF) (56 $01^{\prime}$ $38^{\prime \prime} \mathrm{N} 21^{\circ} 54^{\prime} 46^{\prime \prime} \mathrm{E}$ ) - formed of P. abies, P. silvestris, also Q. robur, C. avellana, Sorbus aucuparia. Sandy loam soil was covered in abundant mosses.

Ruins of abandoned former barracks (RU)

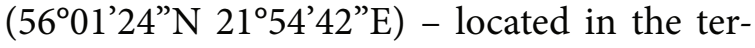
ritory of a former missile defense base. Ruins (bricks) surrounded by P. abies, Padus avium, Urtica dioica. Sandy loam and black soil dominated here.

\section{Sampling and data analysis}

Isopods were sampled directly in habitats, by inspecting natural and artificial shelters in $2 \mathrm{~m}^{2}$ randomly chosen fields. The minimum distance between the plots was $15 \mathrm{~m}$. The $\mathrm{pH}$ of the soil was measured at each site (except Plokštine Reserve) monthly. The collected isopods were preserved in $70 \%$ ethanol and deposited in the personal collection of the author at the Biology Department of Vytautas Magnus University. Taxonomical identification follows Schmalfuss (2003). 
The diversity of isopods in the Plokštine Reserve was assessed by species richness (S), a relative abundance of species, and frequency of occurrence (F, \%). Sampling sites in the Alytus region were assessed by species richness $(\mathrm{S})$, a relative abundance of species, frequency of occurrence (F, \%), Shannon - Wiener diversity index $(\mathrm{H})$, and Simpson dominance index D (Magurran, 2004).

Analysis of variance (one-way ANOVA), ttests, and Spearman correlation analyses computed in PAST 2.12 software (Hammer et al., 2001) were used to test the relationships between isopods and habitats at the level of significance equal to 0.05 .

The distribution and the number of shared species among habitats were assessed by the Jaccard similarity index and were expressed as a dendrogram constructed with a cluster analysis using the free BioDiversity Pro software (McAleece et al., 1997).

\section{RESULTS}

During surveys of isopods in the south and north-western regions of Lithuania, a total of seven species belonging to five families were recorded. Porcellionides pruinosus was recorded from Lithuania for the first time. The list of the recorded taxa, along with the new finding localities and remarks on their biology and prevalence in Europe (based on previous researches by different authors), is presented below.

\section{Taxonomy}

Family Ligiidae Leach, 1814

Genus Ligidium Brandt, 1833

Ligidium hypnorum (Cuvier, 1792)

\section{Material examined}

North-western region of Lithuania: 59 in MCF, $56^{\circ} 01^{\prime} 38^{\prime \prime} \mathrm{N} 21^{\circ} 54^{\prime} 46^{\prime \prime} \mathrm{E}, 11$ May 2016, leg. I. Šatkauskiene; Southern region of Lithuania: $4{ }^{\Uparrow}$ in DF1, 54 $23^{\prime} 44.4^{\prime \prime} \mathrm{N} 24^{\circ} 05^{\prime} 11.1^{\prime \prime} \mathrm{E}, 18$ June 2016, leg. K. Kvašnauskaitè.

\section{Distribution}

Widespread species through Europe (Schmalfuss, 2003), including countries neighbouring Lithuania: Latvia (Spungis, 2008) and Poland (Jędryczkowski, 1981).

Remarks on habitat and ecology in Lithuania The majority of records of L. hypnorum were received from the wet forests in the coastal region of Lithuania (Vilisics et al., 2012). During the current study, L. hypnorum was found in ruins surrounded by coniferous (MCF), also in a damp deciduous forest (DF1) dominated by alders (Alnus sp.) (Table 1). Based on current and previous studies, it is likely that this species is prevalent in damp habitats in Lithuania (Fig. 1).

\section{Remarks}

The genus Ligidium is the most species-rich genus within the family Ligiidae; it has 54 species with a Holarctic and Oriental distribution (Schmalfuss, 2003; Taiti, 2016).

The genus can be diagnosed based on several characters, such as the male pleopod 2 endopod, the male pleopod 1 and 2 exopods, and the uropod, but only the apical tip of male pleopod 2 endopod has the diagnostic value for species delimitation (Vandel, 1965; Li, 2017).

Family Trichoniscidae Sars, 1899

Genus Hyloniscus Verhoeff, 1908

Hyloniscus riparius (Koch, 1838)

\section{Material examined}

Southern region of Lithuania: $15 q, 5 \AA$ in DF1, $54^{\circ} 23^{\prime} 44.4^{\prime \prime N} 24^{\circ} 05^{\prime} 11.1^{\prime \prime} \mathrm{E}, 5$ August 2015, leg. K. Kvašnauskaitė; 6 + in MFP, $54^{\circ} 25^{\prime} 22^{\prime \prime} \mathrm{N}$ $24^{\circ} 03^{\prime} 12^{\prime \prime}$ E, 10 August 2015, leg. K. Kvašnauskaitè.

\section{Distribution in Europe}

H. riparius is found mostly in Central and Eastern Europe, including countries neighbouring of Lithuania: Poland and Latvia (Jędryczkowski, 1981; Jass, Klausmeier, 2003; Spungis, 2008).

Remarks on habitat and ecology in Lithuania In the present study, $H$. riparius was the most abundant in litter of alder leaves and under fallen bark in damp deciduous forest (DF1). Less numerous occurrence of the species was 
observed in mixed forest (MFP) (Table 1). Previous studies recorded sporadical individuals in urban parks and deciduous forest in the central part of Lithuania (Table 2) (Tuf et al., 2012; Šatkauskienè, 2017).

The largest number of $H$. riparius $(\mathrm{N}=98)$ was captured in August with domination of females (79.6\%). It is consistent with Jass and Klausmeier (1996), who reported the increasing occurrence and reproductive activity of H. riparius in August-September.

\section{Remarks}

Jass and Klausmeier (2003) described habitat preferences for $H$. riparius as 'wetlands, riparian'. This isopod quickly desiccates due to its exceptionally small size; also, it lacks pseudotracheae on its abdominal pleopods, which perform the function of conserving body moisture in other terrestrial isopods. Thus, it is more strictly confined to moist habitats than some other terrestrial isopod species.

Genus Trichoniscus Brandt, 1833

Trichoniscus pusillus Brandt, 1833

\section{Material examined}

Southern region of Lithuania: 15 , in BLF, 54 $23^{\prime} 17^{\prime \prime} \mathrm{N} 24^{\circ} 06^{\prime} 17^{\prime \prime} \mathrm{E}, 308$ 2016, leg. K. Kvašnauskaitè

\section{Distribution}

T. pusillus is found commonly across Europe (Schmalfuss, 2003).

Remarks on habitat and ecology in Lithuania Frequency of occurrence of T. pusillus was 50\% in studied habitats of southern Lithuania, with preference of broadleaf forest (Table 1).

\section{Remarks}

T. pusillus is similar to Hyloniscus riparius. Distinguishing characters of $T$. pusillus are their eyes composed of three ocelli (Oldham, 2011) and antenna with four or five flagellar segments; meanwhile $H$. riparius have eyes with one ocellus and the antenna of six segments (Schultz, 1965).

Family Oniscidae Latreille, 1806

Genus Oniscus Linnaeus, 1758

Oniscus asellus Linnaeus, 1758

\section{Material examined}

Southern region of Lithuania: $1 \delta^{\lambda}, 69$ in DF1: $54^{\circ} 23^{\prime} 44.4^{\prime \prime} \mathrm{N} \quad 24^{\circ} 05^{\prime} 11.1^{\prime \prime} \mathrm{E}, 12$ July 2014; Northwest Lithuania region: 49 in MCF: 5601'38”N 2154'46”E, 23 May 2015, leg. I. Šatkauskienè.

\section{Distribution}

O. asellus Linnaeus, 1758 comes from Western Europe, from the Atlantic area (Vandel, 1962) and widespread in Northern and Western Europe (Schmalfuss, 2003). In the north and east of its range, $O$. asellus is considered synanthropic (Bilton, 1994).

Remarks on habitat and ecology in Lithuania Occasional individuals of $O$. asellus were recorded in southern Lithuania during current study (Table 1). Low frequency is possibly related to dry sandy soil dominating in southern Lithuania, since $O$. asellus does not thrive in dry habitats (Dias et al., 2012). Furthermore, soil $\mathrm{pH}$ in sampling sites was $6.7-7.4$, whereas $O$. asellus tolerates lower $\mathrm{pH}$, with a preference for 5.1 (Straalen, Verhoeff, 1997). O. asellus was found in urban parks and natural habitats of previous studies (Tuf et al., 2014; Vilisics et al., 2012; Šatkauskienè et al., 2016).

\section{Remarks}

The family Oniscidae, together with Porcellionidae and Armadillidiidae, are found in drier areas with increased morphological specialisation (Wright, Ting, 2006) and different ability to tolerate dry conditions. O. asellus as epigean clinger species (Schmalfuss, 1984) is the least terrestrial in comparison with Porcellio scaber and Armadillidium vulgare and thus the most susceptible to desiccation (Dias et al., 2012).

Family Porcellionidae Brandt, 1831

Genus Porcellio Latreille, 1804

Porcellio scaber Latreille, 1804

\section{Material examined}

Southern region of Lithuania: 1 i in $\mathrm{AH}$ : $54^{\circ} 23^{\prime} 38^{\prime \prime} \mathrm{N} 24^{\circ} 06^{\prime} 57^{\prime \prime} E$, leg. I. Šatkauskienè 10 July 2015. North-western region of Lithuania: 2 ㅇ in MCF: $56^{\circ} 01^{\prime} 38^{\prime \prime N} 21^{\circ} 54^{\prime} 46^{\prime \prime} \mathrm{E}$, 11 May 2016, leg. I. Šatkauskienè. 


\section{Distribution}

A European species introduced in many parts of the world (Schmalfuss, 2003). Prevalence of this species accompanied by human habitation is recorded in Poland and the Baltic countries (Jedryzckowski, 1981; Spungis, 2008).

Remarks on habitat and ecology in Lithuania Single specimens of Porcellio scaber were found in anthropogenic site (Alytus district) and in mixed coniferous forest (Plungè district) (Table 1). The largest number of captured isopods was reported from coastal habitats (Vilisics et al., 2012).

\section{Remarks}

The first record of $P$. scaber in Lithuania was made by Vilisics (Vilisics et al., 2012). The complete list of the widely studied species $P$. scaber is available in Schmalfuss (2003).

Genus Porcellionides Miers, 1877

Porcellionides pruinosus (Brandt, 1833)

\section{Material examined}

Southern region of Lithuania: $22 \%, 5{ }^{\lambda}$ in

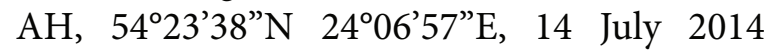
leg. K. Kvašnauskaitė; 3ㅇ 17 July 2016 leg. I. Šatkauskienè.

\section{Distribution}

P. pruinosus is considered to be the most widely distributed species of terrestrial isopods extensively carried elsewhere by humans (Vandel, 1962; Garthwaite, Sassaman, 1985).

Remarks on habitat and ecology in Lithuania In the current study, it was the first time that $P$. pruinosus was found in Lithuania.

$P$. pruinosus was found only in a settlement, dwelt under the bricks of the buildings, in cellars, and manure. The highest number of these isopods (total 343) were collected in July. T. rathkii and $P$. scaber were found in association with $P$. pruinosus, but the domination of the latter species was obvious.

\section{Remarks}

Extensive polymorphism in $P$. pruinosus, with numerous subspecies recognised throughout the world, was described by Vandel (1962). However, subspecific taxa were based solely on morphological criteria, and their biological validity has been questioned repeatedly (Lefebvre and Marcadé, 2005).

Family Trachelipodidae Strouhal, 1953

Genus Trachelipus Budde-Lund, 1908

Trachelipus rathkii (Brandt, 1833)

\section{Material examined}

Southern region of Lithuania: $509,11 \delta$ in MFP, $54^{\circ} 25^{\prime} 22^{\prime \prime} \mathrm{N} 24^{\circ} 03^{\prime} 12^{\prime \prime} \mathrm{E}, 12$ July 2014 leg. K. Kvašnauskaite; north-western region of Lithuania: $10^{\wedge}, 16$ ㅇ in MCF, $56^{\circ} 01^{\prime} 38^{\prime \prime} \mathrm{N}$ $21^{\circ} 54^{\prime} 46^{\prime \prime E}, 23$ May 2015, leg. I. Šatkauskienè.

\section{Distribution}

T. rathkii are widespread through most of Europe (Schmalfuss, 2003; Kuznetsova, Gongalsky, 2012).

\section{Remarks on habitat and ecology in Lithu-} ania

Exhibiting unspecific habitat requirements (Jass, Klausmeier, 1996), T. rathkii, was the most frequent species with occurrence in all habitats during the present study. These isopods showed preference to mixed deciduous forest and were less numerous in recovering young forest and broadleaf forest (Table 1). Based on precursor records, habitats of $T$. rathkii ranged from urban habitats (Vilisics, Hornung, 2009; Tuf et al., 2014; Šatkauskienè et al., 2016) to dune pine forest (Vilisics et al., 2007) and mixed deciduous forest (Šatkauskienè, 2017). During the warm season in Lithuania, females dominated in the studied populations (Šatkauskienè et al., 2016), in agreement with McQueen (1976) and Hornung et al. (2015).

\section{Remarks}

The centre of the geographic distribution of the genus Trachelipus is south-eastern Europe. These species are common in central Europe, and one has been introduced to North America (Schmidt, 1997). Finding additional species Trachelipus difficilis Radu, 1950 and Trachelipus nodulosus is believable in Lithuania since they are distributed in neighbouring Poland and Belarus (Schmidt, 1997; Schmalfuss, 2003). 
Table 1. The number of species, individuals, the relative abundance (in parentheses), and the frequency of occurrence (F) of isopods in sampling sites. Values of diversity indices for the sampling sites in Alytus district

\begin{tabular}{|c|c|c|c|c|c|c|c|c|c|}
\hline Species & MFP & DF & RMF & DDF & AH & BLF & MCF & RU & F \% \\
\hline L. hypnorum & & & & $4(0.92)$ & & & $\begin{array}{c}9 \\
(29.03)\end{array}$ & $\begin{array}{c}15 \\
(62.5)\end{array}$ & 37.5 \\
\hline O. asellus & $1(0.27)$ & & & $3(0.69)$ & & $1(2.22)$ & $\begin{array}{c}3 \\
(9.67)\end{array}$ & & 50.0 \\
\hline P.pruinosus & & & & & $\begin{array}{c}763 \\
(98.2) \\
\end{array}$ & & & & 12.5 \\
\hline P. scaber & & & & & $1(0.13)$ & & $\begin{array}{c}2 \\
(6.45) \\
\end{array}$ & & 25.0 \\
\hline T. rathkii & $\begin{array}{c}325 \\
(88.07) \\
\end{array}$ & $\begin{array}{c}32 \\
(71.1) \\
\end{array}$ & $\begin{array}{c}5 \\
(83.3) \\
\end{array}$ & $\begin{array}{c}83 \\
(19.03) \\
\end{array}$ & $\begin{array}{c}13 \\
(1.67) \\
\end{array}$ & $5(11.6)$ & $\begin{array}{c}17 \\
(54.8) \\
\end{array}$ & $\begin{array}{c}9 \\
(37.5) \\
\end{array}$ & 100 \\
\hline H. riparius & $\begin{array}{c}18 \\
(4.87) \\
\end{array}$ & $\begin{array}{c}1 \\
(2.22)\end{array}$ & $\begin{array}{c}1 \\
(16.6) \\
\end{array}$ & $\begin{array}{c}335 \\
(76.8)\end{array}$ & & $2(4.65)$ & & & 62.5 \\
\hline T. pusillus & $\begin{array}{c}25 \\
(6.77) \\
\end{array}$ & $\begin{array}{c}12 \\
(26.6) \\
\end{array}$ & & $\begin{array}{c}18 \\
(4.12) \\
\end{array}$ & & $\begin{array}{c}35 \\
(81.39) \\
\end{array}$ & & & 50.0 \\
\hline $\mathrm{N}$ & 369 & 45 & 6 & 436 & 777 & 43 & 31 & 24 & \\
\hline $\mathrm{S}$ & 4 & 3 & 2 & 5 & 3 & 4 & 4 & 2 & \\
\hline $\mathrm{D}$ & 0.78 & 0.56 & 0.66 & 0.60 & 0.96 & 0.67 & & & \\
\hline $\mathbf{H}$ & 0.47 & 0.68 & 0.45 & 0.73 & 0.09 & 0.65 & & & \\
\hline
\end{tabular}

$\mathrm{MFP}=$ mixed forest with dominant Pinus silvestris; $\mathrm{DF}=$ deciduous forest on roadside; $\mathrm{RMF}=$ recovering young mixed forest; $\mathrm{DDF}=$ damp deciduous forest; $\mathrm{AH}=$ anthropogenic habitat; $\mathrm{BLF}=$ broadleaf forest, $\mathrm{MCF}(\mathrm{PR})=$ mixed coniferous forest in Plokštinè Reserve; $R U(P R)=$ ruins of building in Plokštinè Reserve; $N=$ total number; $\mathrm{S}=$ species richness; $\mathrm{D}=$ Simpson index; $\mathrm{H}=$ Shannon-Wiener index.

Overall, seven isopod species belonging to seven genera and five families were recorded during this study (Table 1): Ligidium hypnorum, Oniscus asellus, Porcellionides pruinosus, Porcellio scaber, Trachelipus rathkii, Hyloniscus riparius, Trichoniscus pusillus. All seven species were recorded in the studied habitats of southern Lithuania. Four species - T. rathkii, P. scaber, O. asellus, and L. hypnorum - were identified in Plokštinè Reserve (western Lithuania).

It was the first record of Porcellionides pruinosus for Lithuanian isopod fauna.

The maximum number of species (5) and 436 individuals of isopods were found in damp deciduous forest (DF, DDF) and only two species and six individuals were recorded in recovering mixed forest (RMF). Mixed forest (MFP), broadleaf forest (BLF), and mixed coniferous forest (MCF) were represented by four species (Table 1).

T. rathkii was the most frequent $(100 \%)$ in the studied habitats, followed by $H$. riparius (62.5\%) and then O. asellus (50\%) and T. pusillus (50\%), with similar occurrence. P. pruinosus was found only in anthropogenic habitats (Table 1).

T. rathkii and $H$. riparius demonstrated affinity to more appropriate habitats, even though their distribution was observed in the majority of the studied habitats. T. rathkii prevailed (88.07\%) in mixed deciduous forest, and $H$. riparius $(76.8 \%)$ dominated in a damp deciduous forest (DDF) (Table 1).

The correlation between soil $\mathrm{pH}$ and the abundance/species richness of isopods was not statistically significant $\left(\mathrm{R}_{\mathrm{pH} / \mathrm{N}}=0.438\right.$ $\left.p=0.396 ; \mathrm{R}_{\mathrm{pH} / \mathrm{s}}=0.076 ; p=1\right)$. Also, litter $\mathrm{pH}$ 
was found to influence the abundance of isopods only weakly $\left(\mathrm{R}_{\mathrm{pH} / \mathrm{N}}=0.9, p=0.037\right)$.

Shannon-Wiener index had the highest value $(\mathrm{H}=0.73)$ in damp deciduous forest and was at its lowest $(\mathrm{H}=0.09)$ in the anthropogenic habitat dominated by $P$. pruinosus $(\mathrm{D}=0.96)$.

The diversity of isopods was similar (oneway ANOVA, $d f=5 F=0.711 p=0.618)$ in the surveyed habitats.
The cluster analysis based on Jaccard similarity index indicated similarities between the compositions of isopod species recorded in habitats. The mixed and broadleaf forests revealed the highest similarity between isopod communities (>90\%). The anthropogenic habitat stood out clearly from other habitats and showed the lowest $(0.17 \%)$ similarity in species composition (Fig. 2).

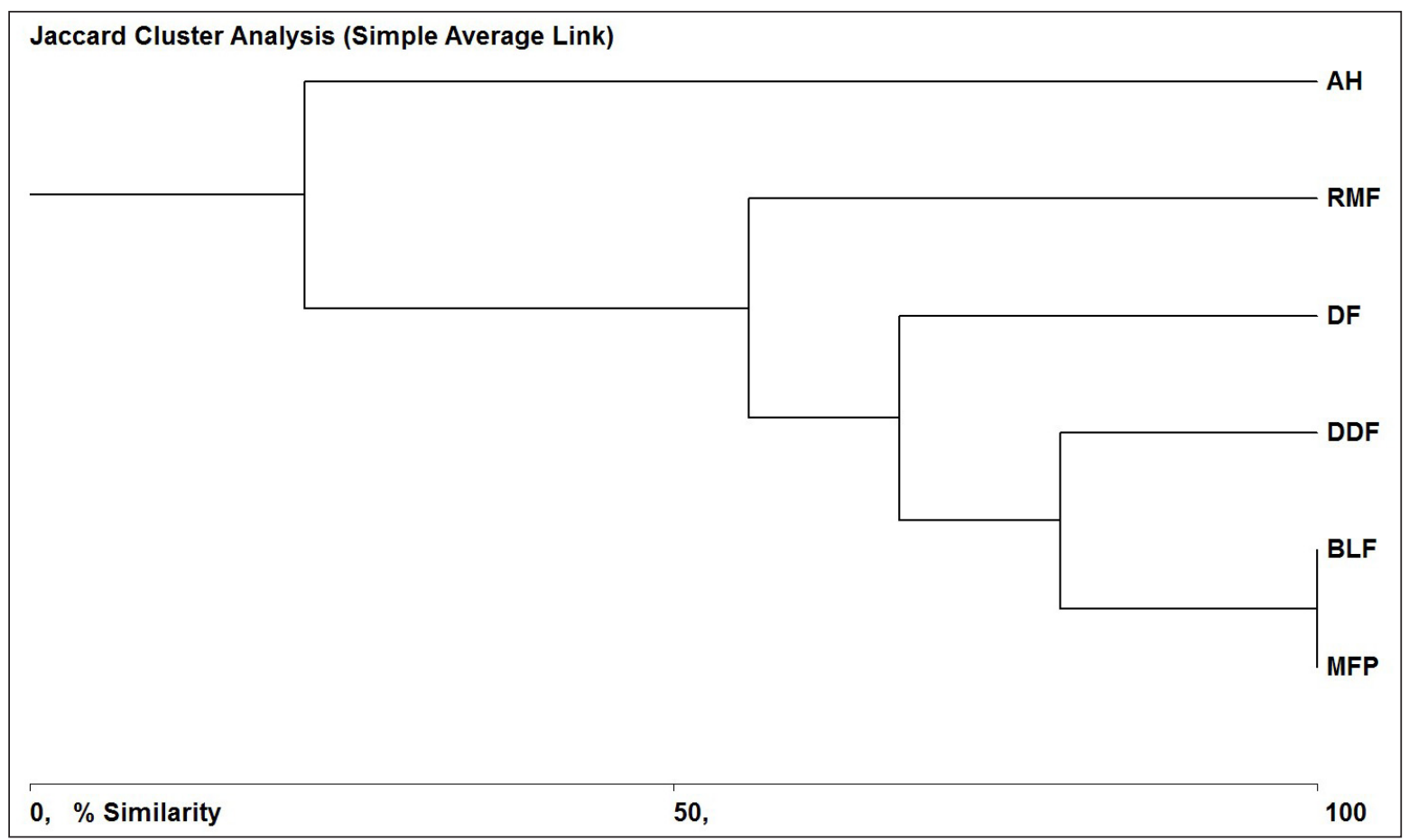

Fig. 2. Dendrogram constructed by the data on similarity (Jaccard index) of isopods community between habitats in Alytus region, Lithuania $(\mathrm{AH}=$ Anthropogenic habitat $\mathrm{RMF}=$ Recovering young mixed forest; DF $=$ Deciduous Forest on roadside DDF $=$ Damp deciduous forest $;$ BLF = Broadleaf Forest MFP = Mixed Forest with dominant Pinus silvestris)

\section{DISCUSSION}

Distribution and richness of species in habitats According to the present study, seven species of terrestrial isopods are widespread in Europe (Schmalfuss, 2003). T. rathkii as habitat generalist (Hornung et al., 2007; Hornung et al., 2015 ) is most frequent, with occurrence in all the studied habitats. Although $H$. riparius was found in most habitats, being sensitive to desiccation (Jass, Klausmeier, 2003) gave a clear preference $(76.8 \%)$ to damp deciduous forest.
The relation between soil/litter properties and isopod communities was determined as weak $(p>0.05)$ during the present study.

On the other hand, soil/litter - together with other environmental factors such as moisture, plant community, and microhabitats - often incorporates into a collective set and acts together creating a more or less suitable background for isopod communities, as in the case of damp deciduous forest (DDF), in which highest diversity $(\mathrm{H}=0.73)$ and five species were recorded (Table 1). Well-developed 
litter of alder leaves as energy-efficient food for isopods (Loureiro et al., 2006), moisture, and shadows of the canopy formed suitable habitat for isopods.

Since a typical forest isopod community consists of 3-7 species (Farkas et al., 1999), the diversity of isopods found in damp forest can be assumed as average rich.

The lowest species richness and only a few specimens (Table 1) were observed in recovering forest (RMF). Young pines and birches, with a scarce canopy, do not form a shadow and litter, and, as a consequence, do not create a suitable environment for isopods.

An anthropogenic environment with an abundance of shelters and food sources are often suitable for synanthropic isopods. In this study, a settlement was the first and only place of finding P. pruinosus. Prevalence (98.19\%) of anthropophilic P. pruinosus (Radu, 1985) in such a place (Table 1) can be assigned to the available manure-like food source (Cawley, 1996) or, possibly, adaptation of this species to higher temperatures (Römbke et al., 2011) characteristic of southern Lithuania. In any case, the distribution of $P$. pruinosus in Lithuania remains unclear and needs further studies.

Similar communities consisting of T. rathkii, $H$. riparius, and $T$. pusillus were found in mixed (MFP) and broadleaf forest (BLF). However, the rich cover of moss in MFP, ensuring a more suitable living space for isopods (Božanić et al., 2013) probably determined the highest abundance of isopods in this habitat in comparison with BLF.

Relatively low diversity of isopods in Plokštine Reserve (Table 1) was most likely due to brief inspection of the habitats and to prevailing coniferous (Table 1 ).

In general, the average richness of species (2-5) was determined in habitats of southern Lithuania, comparing with 11 species that were recorded in one mixed deciduous forest in the Kaunas region (Šatkauskienè, 2017). It could be related to the rather complicated environment for isopods in southern Lithuania. Pine forests, dominant in this region, generate low-quality litter resulting in restricted litter shelter (Loureiro et al., 2006), so probably limiting the diversity of isopods in such an environment. In addition, it is likely that the prevalence of sandy soil in most areas of Alytus district creates less favorable soil conditions for isopods: sand is characterised by low water-holding capacities and as low in all essential nutrients, which are significant factors for isopods and myriapods (Kula, Lazorik, 2017).

\section{Review of the isopod fauna in Lithuania}

This section aims to overview the available knowledge on isopods in Lithuania, including records of the present study. The previous faunistic studies (Kuznetsova, Gongalsky, 2012; Vilisics et al., 2012; Tuf et al., 2014; Šatkauskienè et al., 2016; Šatkauskienè, 2017) resulted in 13 isopod species. The first record of Porcellionides pruinosus during the present study extended the list of species of Lithuanian isopods to 14 (Table 2).

All recorded Lithuanian isopod species are common in Europe (Schmalfuss, 2003).

O. asellus, P. scaber, and T. rathkii are widely distributed in Lithuania, with occurrences in a wide range of habitat types (Fig. 1, Table 2).

$P$. scaber, often regarded as an urban environment specialist (Magura et al., 2008), demonstrated a preference for natural dry habitats in Lithuania. Most records of this woodlouse were obtained from the coast of the Baltic Sea (Vilisics et al., 2012), while these isopods were less numerous in city parks in the central part of the country (Tuf et al., 2014; Šatkauskienè et al., 2016). A similar distribution of this species in dry coastal dune meadows and pine forests in Latvia were recorded as well (Spungis, 2008).

Cylistiscus convexus and P. pruinosus occur in a wide range of natural and human-affected areas in Europe (Vandel, 1962; Garthwaite, Sassaman, 1985; Schmalfuss, 2003; Vilisics, Hornung, 2009); however, only two records were received from two localities in Lithuania (Table 2). Since the occurrence of these isopods is sporadic in neighbouring countries (Jedryzckowski, 1981; Spungis, 2008), its distribution is 
Table 2. Updated list of terrestrial isopod species recorded in Lithuania (based on previous research and the present survey)

\begin{tabular}{|c|c|c|c|c|c|c|c|c|}
\hline No. & Family/species & 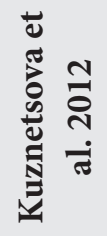 & 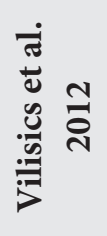 & 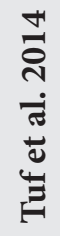 & 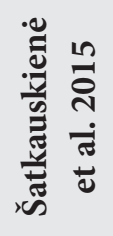 & N & 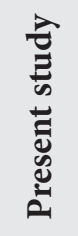 & 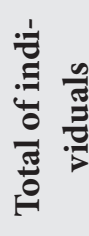 \\
\hline \multicolumn{9}{|c|}{ Ligiidae Brandt \& Ratzeburg, 1831} \\
\hline 1 & Ligidium hypnorum (Cuvier, 1792) & & 320 & 75 & & 1 & 28 & 424 \\
\hline \multicolumn{9}{|c|}{ Trichoniscidae Sars, 1899} \\
\hline 2 & Haplophthalmus danicus Budde Lund 1880 & & & 4 & & 5 & & 9 \\
\hline 3 & Hyloniscus riparius (C. Koch, 1838) & & & 5 & & 1 & 357 & 363 \\
\hline \multirow[t]{2}{*}{4} & Trichoniscus pusillus Brandt, 1833 & & & 17 & & 15 & 90 & 122 \\
\hline & Platyarthridae Vandel, 1946 & & & & & & & \\
\hline \multirow[t]{2}{*}{5} & Platyarthrus hoffmannseggii Brandt, 1833 & & & & & 5 & & 5 \\
\hline & Oniscidae Latreille, 1806 & & & & & & & \\
\hline \multirow[t]{2}{*}{6} & Oniscus asellus Linnaeus, 1758 & + & 17 & 10 & 1 & 20 & 8 & 56 \\
\hline & Porcellionidae Brandt \& Ratzeburg, 1831 & & & & & & & \\
\hline 7 & Porcellio scaber Latreille, 1804 & + & 269 & 14 & 24 & 6 & 3 & 316 \\
\hline 8 & Porcellio spinicornis Say, 1818 & + & & 2 & & & & 2 \\
\hline 9 & Porcellium conspersum (C. Koch, 1841) & & 50 & 4 & & & & 54 \\
\hline \multirow[t]{2}{*}{10} & ${ }^{*}$ Porcellionides pruinosus (Brandt, 1833) & & & & & & 763 & 763 \\
\hline & Trachelipodidae Strouhal, 1953 & & & & & & & \\
\hline \multirow[t]{2}{*}{11} & Trachelipus rathkii (Brandt, 1833) & + & 1942 & 68 & 988 & 48 & 489 & 3535 \\
\hline & Cylitiscidae & & & & & & & \\
\hline \multirow[t]{2}{*}{12} & Cylistiscus convexus (De Geer, 1778) & & 1 & & & & & 1 \\
\hline & Armadillidiidae & & & & & & & \\
\hline 13 & Armadillidium vulgare (Latreille, 1804) & & & 2 & & 5 & & 7 \\
\hline 14 & Armadillidium pulchellum (Zenker, 1799) & + & & 5 & & 20 & & 25 \\
\hline
\end{tabular}

possibly similar in Lithuania as well, but more detailed studies are needed for confirmation of the statement.

Although widespread in Europe, myrmecophilous Platyarthrus hoffmannseggii (Forró, Farkas, 1998; Schmalfuss, 2003) was found only in Kaunas district until now. (Table 2; Fig. 1). However, this single site of occurrence is most likely an inaccuracy due to pitfall trapping used in previous studies. Small underground isopods usually do not fall in pitfall traps (Ianc, Ferenti, 2014); meanwhile, about half of the data from previous studies (Vilisic et al., 2012; Tuf et al., 2014; Šatkauskienè et al., 2016) were based on pitfall traps.

Till now, most data on isopods are available from central (Kaunas region) (Tuf et al., 2014; Šatkauskienè et al., 2016; Šatkauskienė, 2017) and south-western Lithuania (Kuznetsova and Gongalsky, 2012; Tuf et al., 2014; and present study), with records of eleven and eight species, respectively. The highest species richness recorded in Kaunas district was probably influenced by direct sampling and checking of 
litter in old mixed deciduous forest, generating an optimal habitat for the majority of isopods (Šatkauskienè, 2017).

The western part of the country, the main coast of the Baltic Sea, is represented by six common species of isopods, which are capable to adapt to the coastal environments harsh for isopods (Vilisics et al., 2012).

In summary, 14 species of isopods are recorded in the fauna of Lithuania but the presence of still another few species is plausible since about 20 isopod species are recorded in neighboring Latvia (Spungis, 2008). Most regions of Lithuania remain unexplored and knowledge on the isopod fauna is still incomplete. Since richness of isopods is highly correlated with geographical and landscape complexity, and environmental heterogeneity (e.g., Mediterranean) (Sfenthourakis, Taiti, 2015), we probably could not expect very high species richness due to the flat terrain and rugged climate of Lithuania. However, the forested area covers approximately $33 \%$ of the territory (19\% of mature old forests) (Lithuanian Statistical Yearbook of Forestry 2015), it provides a suitable environment for isopods and suggests finding more isopod species during further investigations.

\section{CONCLUSIONS}

Seven species of terrestrial isopods were found in habitats of the southern and north-western regions of Lithuania. As a habitat generalist, Trahelipus rathkii was the most frequent, with occurrences in all the studied habitats. Porcellionides pruinosus was recorded for the first time for the Lithuanian isopod fauna.

Summarising of available data on isopods in Lithuania , including the records of the present study and the previous faunistic studies (Kuznetsova, Gongalsky, 2012; Vilisics et al., 2012; Tuf et al., 2014; Šatkauskienè et al., 2016; Šatkauskienè, 2017), 14 isopods species are recorded in Lithuania.

Received 5 July 2021 Accepted 2 August 2021

\section{References}

1. Bilton DT. Intraspecific variation in the terrestrial isopod Oniscus asellus Linnaeus, 1758 (Crustacea: Isopoda: Oniscidea). Biol J Linn Soc. $1994 ; 110(4)$ : 325-54.

2. Božanić B, Hradílek Z, Machač O, Piž V, Štáhlavský F, Tufová J, Véle A, Tuf IH. Factors affecting invertebrate assemblages in bryophytes of the Litovelské Luhy National Nature Reserve, Czech Republic. Acta Zool Bulg. 2013; 65(2): 197-206.

3. Brandt JF, Ratzeburg JTC. Medizinische Zoologie oder getreue Darstellung und Beschreibung der Thiere, die in der Arzneimittellehre in Betracht kommen. 1831; 2: i-iv, $1-364$.

4. Brandt JF. Conspectus monographiæ crustaceorum oniscodorum Latreillii. Bull Soc Nat Moscou. 1833; 6: 171-93.

5. Broly P, Deville P, Maillet S. The origin of terrestrial isopods (Crustacea: Isopoda: Oniscidea). Evol Ecol. 2013; 27: 461-76.

6. Bukantis A, Ignatavičius G, Satkūnas J, Sinkevičius S, Šulijienè G, Vasarevičius S, et al. [Lithuanian natural environment: state, processes and development]. Vilnius: Kopa; 2013. Lithuanian.

7. Budde-Lund G. Isopoda von Madagaskar und Ostafrika mit Diagnosen verwandter Arten. In: Voeltzkow A. (Ed.) Reise in Ostafrika in den Jahren 1903-1905. Wissenschaftliche Ergebnisse, Stuttgart, 1908; (2): 265-308.

8. Cawley M. The woodlice (Crustacea, Isopoda) of Cos Sligo and Leitrim. Ir Nat J. 1996; 25(8): 273-7.

9. Cuvier G. Mémoire sur les Cloportes terrestres. J Hist Nat Paris. 1792; 2: 18-31.

10. Dias N, Hassall M, Waite T. The influence of microclimate on foraging and sheltering behaviours of terrestrial isopods: Implications for soil carbon dynamics under climate change. Pedobiologia. 2012; 55: 137-44. 
11. Farkas S, Hornung E, Morschhause T. Composition of isopod assemblages in different habitat types. In: Tajovský K, Pižl V (Eds.) Soil Zoology in Central Europe. Institute of Soil Biology AS CR, České Budějovice, 1999, 37-44.

12. Forró L, Farkas S. Checklist, preliminary distribution maps, and bibliography of woodlice in Hungary (Isopoda: Oniscidea). Miscnea zool hung. 1998; 12: 21-44.

13. Garthwaite R, Sassaman C. Porcellionides floria, new species, from North America; provinciality in the cosmopolitan isopod Porcellionides pruinosus (Brandt). J Crust Biol. 1985; 3: 539-55.

14. Hammer ODA, Harper T, Ryan PD. "PAST: Paleontological Statistics Software Package for Education and Data Analysis. Palaeontol Electron. 2001; 4: 1-9.

15. Hornung E, Warburg MR. Isopod distribution at different scaling levels. Terrestrial Isopod Biology (ed. A. M. Alikhan). 1995; 83-95.

16. Hornung E, Tóthmérész B, Magurran T, Vilisics F. Changes of isopod assemblages along an urban-suburban-rural gradient in Hungary. Eur J Soil Biol. 2007; 43: 158-61.

17. Hornung E. Evolutionary adaptation of oniscidean isopods to terrestrial life: structure, physiology and behavior. Terr Arthropod Rev. 2011; 4: 95-130.

18. Hornung E, Szlavecz K, Dombos M. Demography of some non-native isopods (Crustacea, Isopoda, Oniscidea) in a Mid-Atlantic forest, USA. In: Taiti S, Hornung E, Štrus J, Bouchon D (Eds.) Trends in Terrestrial Isopod Biology. ZooKeys. 2015; 515: 127-43.

19. Ianc RM, Ferenti S. Data upon the terrestrial isopod assemblages from Pădurea Craiului Mountains karst area, western Romania. North West J Zool. 2014; 10(1): S87-93.

20. Jass J, Klausmeier B. Comparison of Wisconsin terrestrial isopods and their life cycle traits. Field Station Bulletin. 1996; 29(2): 14-26.

21. Jass J, Klausmeier B. The terrestrial isopod Hyloniscus riparius (Isopoda: Oniscidea: Tri- choniscidae) in Wisconsin. Gt Lakes Entomol. 2003; 36(1-2): 70-5.

22. Jędryczkowski W. Isopods (Isopoda) of Warsaw and Mazovia. Polish Academy of Sciences. Institute of Zoology Memorabilia. 1981; 34: 79-86.

23. Koch CL. Deutschlands Crustaceen, Myriopoden und Arachniden. 1835-1844; Hefte 6, 22, 28, 34 and 36. Regensburg.

24. Kula E, Lazorik M. Myriapods and Isopods of Spruce and Beech Mountain Forests in the Moravian - Silesian Beskids. Balt For. 2017; 23(2): 342-55.

25. Kuznetsova DM, Gongalsky KB. Cartographic analysis of woodlice fauna of the former USSR. ZooKeys. 2012; 176: 1-11.

26. Latreille PA. Famille Seconde. Cloportides. In: Buffon L and Sonnini CS (Eds.), Histoire naturelle générale et particulière des Crustacés et des Insectes. Paris, 1804; 7: 25-49.

27. Latreille PA. Genera crustaceorum et insectorum. Paris. 1806; 1: 302 pp.

28. Lefebvre F, Marcadé I. New insights in the Porcellionides pruinosus complex (Isopoda, Oniscidea): Biological, behavioural, and morphological approaches. Crustaceana. 2005; 78: 465-80.

29. Li WC. Morphology and molecules reveal high species diversity of Ligidium (Crustacea: Oniscidea: Ligiidae) in Jiangxi, China Zool J Linnean Soc. 2017; 179(3): 627-41.

30. Linnæus C. Systema naturae per regna tria naturae, secundum classes, ordines, genera, species, cum characteribus, differentiis, synonymis, locis. Laurentii Salvii, Holmiae. 1758; Tomus I, Editio decima, reformata: i-ii, 1-824.

31. Lithuanian Hydrometeorological Service under the Ministry of Environment. http://old. meteo.lt/english/links.php

32. Lithuanian Statistical Yearbook of Forestry. Vilnius, 2015. http://www.amvmt.lt/index. php/leidiniai/misku-ukio-statistika/2015

33. Loureiro S, Sampaio A, Brandão A, Nogueira AJA, Soares AMVM. Feeding behavior of 
the terrestrial isopod Porcellionides pruinosus Brandt, 1983 (Crustacea, Isopoda) in response to changes in food quality and contamination. Sci Total Environ. 2006; 369: 119-28.

34. Magurran AE. Measuring biological diversity. Oxford: Blackwell Publishing; 2004.

35. Magura T, Tóthmérész B, Hornung E, Horváth $\mathrm{R}$. Urbanisation and ground-dwelling invertebrates. In: Wagner LN (ed.) Urbanization: 21st Century Issues and Challenges. 2008: 213-25.

36. Mažvila J, Adomaitis T, Eitminavičius L. [Changes in the acidity of Lithuanian soils without liming them]. Žemdirbystè. Mokslo darbai 2004; 4(88): 3-20. Lithuanian.

37. McAleece N, Gage JDG, Lambshead PJD, Paterson GLJ. BioDiversity Professional statistics analysis software. Jointly developed by the Scottish Association for Marine Science and the Natural History Museum London. 1997. http://www.sams.ac.uk

38. Oldham MJ. Occurrence of the woodlouse, Hyloniscus riparius (Koch) (Isopoda: Trichoniscidae), in Ontario. J Entomol Soc Ont. 2011; 142: 49-52.

39. McQueen DJ. The influence of climatic factors on the demography of the terrestrial isopod Tracheoniscus rathkei Brandt. Can J Zool. 1976; 54: 2185-99.

40. Miers EJ. On a collection of Crustacea, Decapoda and Isopoda, chiefly from South America, with descriptions of new genera and species. Proc Zool Soc Lond. 1877; 1877: 653-79.

41. Radu VG. Rivizuire critica a speciei de isopod cavernicol; Mesoniscus alpicolus vulgaris (Chappuis, 1944). Academia Republicii Populare Romaine, Bulletin Stiintific, Sectia de Geologie si Geografie. 1950; 2(3): 159-65.

42. Radu VG, Fauna RSR. Crustacea. vol. IV, Fascicola 14 Ordinul Isopoda, Subordinul Oniscoidea, Crinochaeta. Edit. Academiei R. S. R. Bucureşti. 1985; p. 158.
43. Römbke T, Römbke J, Russell D. Effects of temperature increases on the feeding activity of two species of isopods (Porcellio scaber, Porcellionides pruinosus) in laboratory tests. Soil Org. 2011; 83: 211-20.

44. Šatkauskiene I. New record and additional data about terrestrial isopods in Kaunas region, Lithuania. Bulletin of the Lithuanian entomological society. 2017; 29: 129-31.

45. Šatkauskienè I, Hornung E, Lelešius E, Kvašnauskaitė $K$, Ašmantas Š. Preliminary study on the terrestrial isopods of Kaunas city (Lithuania). Zool Ecol. 2016; 26(1): 22-7.

46. Schmalfuss H. Eco-morphological strategies in terrestrial isopods. In: Sutton SL, Holdich DM (Eds.) The biology of terrestrial isopods. Symposia of the Zoological Society of London. 1984; 53: 97-107.

47. Schmalfuss H. World catalog of terrestrial isopods (Isopoda: Oniscidea). Stutt Beitr Naturkd. 2003; 654: 1-341.

48. Schmidt C. Revision of the European species of the genus Trachelipus Budde-Lund, 1908 (Crustacea: Isopoda: Oniscidea). Zool J Linn Soc. 1997; 121: 129-244.

49. Schultz GA. The distribution and general biology of Hyloniscus riparius (Koch) (Isopoda, Oniscoidea) in North America. Crustaceana. 1965; 98: 131-40.

50. Sfenthourakis S, Taiti S. Patterns of taxonomic diversity among terrestrial isopods. In: Taiti $S$, Hornung E, Štrus J, Bouchon D (Eds.) Trends in Terrestrial Isopod Biology. ZooKeys. 2015; 515: 13-25.

51. Spungis V. Fauna, distribution, habitat preference and abundance of woodlice (Oniscidea) in Latvia. Entomological Society of Latvia. Latvijas Entomologs. 2008; 45: 25-37.

52. Straalen NM, Verhoeff H. The development of a bioindicator system for soil acidity based on arthropod pH preferences. J Appl Ecol. 1997; 34(1): 217. 
53. Tuf IH, Ivinskis P, Rimšaitė J. Four terrestrial isopod species (Isopoda: Oniscidea) new for Lithuanian fauna and data on distribution of another seven species. New and Rare for Lithuania Insect Species. 2014; 26: 86-9.

54. Vandel A. Faune de France - Isopodes terrestres. Chevalier (Ed), Paris. 1962; 66: pp 416.

55. Verhoeff KW. Über Isopoden. 15. Aufsatz. Archiv für Bio Berlin. 1909; 2: 335-87. In German.

56. Vilisics F, Elek Z, Lövei G, Hornung E. Composition of terrestrial isopod assemblages along an urbanisation gradient in Denmark. Pedobiologia. 2007; 51: 45-53.

57. Vilisics F, Hornung E. Urban areas as hot-spots for introduced and shelters for native isopod species. Urban Ecosyst. 2009; 12: 333-45.

58. Vilisics F, Ivinskis P, Rimšaite J. Terrestrial isopods (Crustacea, Oniscidea) at the Baltic Sea coast in Lithuania. Zool Ecol. 2012; 22(3-4): 226-32.

59. Wright JC, Ting K. Respiratory physiology of the Oniscidea: Aerobic capacity and the significance of pleopodal lungs. Com Biochem Phys. 2006; 145: 235-44.

60. Zimmer M. Nutrition in terrestrial isopods (Isopoda: Oniscidea): an evolutionary-ecological approach. Biol Rev. 2002; 77: 455-93.

\section{Ingrida Šatkauskienė}

\section{INDĖLIS İ LIETUVOS SAUSUMOS LYGIAKO- JŲ VÉŽIAGYVIŲ PAŽINIMĄ}

\section{Santrauka}

Straipsnyje pateikiamos sausumos lygiakojų věžiagyvių rūšys, rastos 2014-2016 metais Pietų ir Šiaurès vakarų Lietuvos vietovèse. Véžiagyviai surinkti tiesiogiai rankomis apžiūrint slèptuves ir substratą aštuoniuose (skirtingi miško tipo biotopai ir antropogeninès veiklos zonos biotopas) biotopuose. Iš viso rastos ir identifikuotos septynios sausumos lygiakojų vėžiagyvių rūšys. Europoje ịprastinè ir dažna Trachelipus rathkii rūšis buvo randama visuose tirtuose biotopuose. Antropogeninès veiklos zonos biotope rasta nauja Lietuvai rūšis Porcellionides pruinosus. Remiantis gautais rezultatais ir ankstesnių autorių tyrimais, Lietuvoje šiuo metu nustatyta 14 sausumos lygiakojų vèžiagyvių rūšių.

Raktažodžiai: véžiagyviai, lygiakojai, vėdarèliai, Lietuva 